\title{
Widowed Household Heads and the New Boundary of the Family
}

With the beginning of Japanese colonial rule, many things about women and their position in the family were transformed. At the base of the legal structure implemented in the colonies and the status of women within it was the family system that had developed in Japan in the Meiji era. Ordained in the Meiji Civil Code (1898), the formal framework of the Japanese family system (ie-seido), or the household system, embodied the Japanese political ideology of the family state, which literally, figuratively, and ideologically captured the Japanese citizenry into one large big national family under the paternal authority of the emperor. It is this family system that the Japanese tried to transplant in colonial Korea through the colonial legal system and the household registry.

The impact of the colonial transformation of the traditional family system was complex for the colonized, especially for some of the women and widows who occupied a marginal position in society and found new opportunities in the volatile legal environment that colonial rule engendered. The Japanese family system had a transformative effect in Korea, as it did in Japan, specifically by creating an official boundary around the unit of household, which weakened the traditional lineage system. The new administrative unit of the household restructured family relations; each household was an administrative unit as well as a legal unit, firmly placed under the administrative authority of the household head. These were made manageable and legible to the state through the household registry (koseki). The operation of the modern colonial legal system systematized adjudication processes, cutting the operative power of the cultural and customary authority of family elders and significantly boosting certain women's standing in legal struggles against family elders. Widows, whose position in the family had 
long been threatened, found an official and systematized route to have their pleas addressed.

In this chapter I examine the impact of the colonial household system through records of civil cases that involve widows and their customary rights. Rather than resort to suicide to express their resentment, as did those widows from the late nineteenth century we encountered in the previous chapter, widows under Japanese colonial rule proactively utilized the colonial legal system to claim their customary rights over property and often won. Yet these victories had their limitations. Since strengthened widow rights were an accouterment of strengthened household-head rights, widows' rights still were vulnerable once a male heir was secured through adoption. A widow's house headship remained temporary, as a later case we examine at the end of the chapter illustrates through one widow's vain attempt to make her tenure as household head permanent.

\section{JAPANESE FAMILY POLICIES AND THE COLONIAL}

\section{LEGAL SYSTEM}

The Ordinances on Civil Matters (Chōsen Minjirei) promulgated in 1912 extended the Japanese Civil Code in its entirety in Korea, with the important exceptions of family and inheritance matters, which were designated to be ruled according to Korean custom. ${ }^{1}$ Family customs thus were meant to play a prominent role in the colonial civil-law regime. An immediate problem, however, was that Korea lacked any codified set of customary laws. Following the tradition of Chinese legal culture, Korea had long left most civil matters to be dealt with privately, handled by local magistrates only when they were considered harmful to public order. ${ }^{2}$ Without a tradition of private law, there also was no history of customary law formation. ${ }^{3}$ To fill this gap, the Japanese conducted customs surveys to collect material to determine Korean customs in practice. The result, published later in 1912 as Kanshū chōsa hōkokusho (Customs-survey report), was used in the colonial courts as a reference on Korean customs in conjunction with additional surveys and inquiries, though these by no means were sufficient to cover all matters that came to the colonial civil courts. In addition, the discrepancy between the civillaw regime in precolonial Korea and the Japanese Civil Code meant that there was bound to be some adjustment, if not outright distortion, of customs in the process of their becoming customary law.

For leadership in the colonies, the operation of a customary law regime served some important political objectives. As with Taiwan, the governor general of Korea answered directly to the emperor, bypassing the Japanese Diet. Establishing colonies as separate legal spheres ensured political ease of control and enabled a flexibility that facilitated the transition to colonial rule. The Japanese authorities were concerned that applying foreign laws to private affairs, such as family matters, might cause too much disruption to local society. As a latecomer to empire 
building, the Japanese were positioned to take cues from other colonizers, such as the British, German, and the French, who applied local customs in matters of family and religion. ${ }^{4}$

That keeping Korea as a separate legal sphere was the main objective of the customary laws is proven by the fact that locating the Korean difference in family matters was not always part of the plan. The choice to do so was derived from a long and rather haphazard process. Japanese influence on Korean legal matters began with protectorate rule in 1905, even before Korea was formally annexed to Japan in 1910. Rescinding the unequal treaties and thus severing the Western countries' ties to Korea was crucial to Japan's monopolization of Korea-a fact of which the Japanese resident general, Itō Hirobumi, was acutely aware. ${ }^{5}$ Itō recognized a pressing need for a proper system of civil law in what he saw as a still chaotic legal system in Korea. As the first step toward legal reform, Itō formed a system of legal advisers. Judges and lawyers from Japan were invited to local regions in Korea to "advise and assist" the Korean administrator-judges in legal matters. Korea's 1895 efforts to modernize the judicial system during the Kabo Reforms by implementing new judicial procedures had fallen far short of what had been achieved in the Japanese legal system. ${ }^{6}$ Civil cases and criminal cases remained undivided, and local administrators doubled as judges. Without any legal or administrative authority, however, the Japanese legal advisers had limited means of directly implementing reforms of the local courts.

For the reform of the framework within which these courts operated, Itō, with a background in law and having himself been a significant contributor to the writing of the Japanese Constitution, envisioned a civil law for Korea separate from the Japanese Civil Code. To write such civil law, Itō included among the legal advisers he invited to Korea Ume Kenjirō (1860-1910), a prominent civil-law scholar who had participated in the writing of Japan's Civil Code.? In Japan Ume had been a member of the Enactment Faction (Dankō-ha) and had supported a Civil Code based on universal principles rather than Japanese customs. Yet in Korea he supported a Civil Code more agreeable to local customs. What is notable is that, unlike the customary law regime enacted later in 1912, Ume's plan was to produce separate laws for commercial matters in Korea based on its customs but extend Japanese family laws to Korean family matters. Accordingly, Ume's customs surveys concentrated on customs concerning land, such as ownership, transactions, land tenure, and tenancy.

The sudden shift of Japan's Korea policy in 1909, following a whirlwind of events, turned the legal policy on civil laws in Korea on its head. In 1907 King Kojong's attempt to publicize his discontentment with Japanese control failed at the Hague Convention. In the aftermath of this incident, the Japanese forced King Kojong's abdication and assumed control over legal and diplomatic matters in Korea. Following the assassination of Itō Hirobumi by An Chung-gŭn, a Korean nationalist, the Consignment of Judicial Power in November 1909 nullified the 
need to write new civil laws for Korea. Japan discarded its plan to keep Korea as a protectorate and signed the Annexation Treaty in 1910 to formally colonize Korea. ${ }^{8}$ Ume's original plan came to naught, and, shortly after, in August 1910, Ume himself died from typhoid fever.

Despite the tumult of the times, legal reforms after 1910 were carried out with smooth continuity under the supervision, in part, of the same legal experts already on the ground since 1906. They were joined by many legal specialists newly recruited after 1910 with attractive pay and benefits. ${ }^{9}$ Shifting away from Ume's original plan, the overall direction of reform was toward legal assimilation, whereby the new modern Japanese laws and legal system would be implemented almost wholesale in Korea. Korean exception became confined to the area of family matters, thereby giving family customs a more prominent role in defining the Korean difference.

Legal reform in Korea was later remembered by its implementers as a smooth and optimistic march toward progress. One judge, Yamaguchi Sadamasa, reminisced in 1940 about how ecstatic he had been over the transfer of legal matters in 1909: his decision to come to Korea, which was an ambitious career gamble for a young legalist, had finally paid off. The happy sentiment was shared by many, and the Japanese legalists celebrated the occasion with various festivities. At the old site of Kyŏnghŭi Palace they held a sports meet (daiundōkai) and a costume ball, where they dressed up as British and German officers and European ladies; they also marched in a costume parade. ${ }^{10}$ The Government General installed a modern court system modeled on Japan's own in 1909, even with similar court names, and began implementing divisions between judicial and administrative duties as well as between penal and civil matters.

The colonial civil-court system, formalized in 1912, had three levels, consisting of eight local courts, three appellate courts (fukushin hōin), and a High Court (kōtō höin). Litigating parties commonly had legal representatives or lawyers, either Korean or Japanese, although even at the highest level of the High Court some cases were litigated by the plaintiffs or defendants themselves. ${ }^{11}$ Lawsuits were quite expensive; one had to pay the lawsuit filing fee of 3.50 wŏn. If one hired a scribe, which seems to have been the common practice, one paid an additional 5.00-6.00 wŏn, bringing the total to around 10.00 wŏn. Considering that an average female factory worker's monthly earnings were around 12.00 wŏn, filing a lawsuit must not have been undertaken lightly. ${ }^{12}$ The filing fee, moreover, was only part of the challenge. A scene in Kim Tong-in's short story "Yakan jaŭi sŭlp'ŭm" (Sadness of the weak, 1919) provides a sense, albeit fictional, of the economic realities of a lawsuit for a person of modest income. In this story a young female student is impregnated by her employer and sues him for compensation. As an orphan from a poor, rural family, putting herself through school by working as a live-in tutor in an affluent household, she can afford a lawsuit only because she receives an unexpected severance payment from the employer's wife. Her limited monetary power, 
however, inhibits her from hiring a lawyer, which proves to be a critical disadvantage against the defendant, who hires a very eloquent professional. ${ }^{13}$

\section{INVENTED CUSTOMS}

Much ink has been spilled about how accurate or distorting the survey process was for Korean family customs. This process was very much influenced by the Japaneseintroduced household system in addition to the logic of customary lawmaking. Countering the conventional understanding that the survey distorted, or "misinterpreted," Korean custom, scholar Yi Sŭng-il more recently has argued that the changes in customary law merely reflected the natural change of customs themselves under colonial rule. ${ }^{14}$ Marie Seong-hak Kim has argued that the colonial survey process of customary laws was inadvertently a process of the "invention of tradition." Owing to their invented nature, Kim notes, the customary laws of colonial Korea lacked the critical component of customary laws in European cases: communal consensus. Since customary laws were produced through judicial processes in a very short period compared to the long historical processes through which European customary laws were created, Koreans themselves ironically were marginalized in the creation process of the very customs that they supposedly embraced. It was not surprising that Korean litigants commonly claimed that the Korean customs cited as the basis on which the colonial courts adjudicated were inauthentic. What was happening was that Korean custom (Chōsen kanshū) was not exactly what Koreans were practicing customarily, but rather a set of customs artificially created by the colonial judicial system through a process of replies (kaitō) and bulletins $(t s \bar{u} c h \bar{o}){ }^{15}$

In fact, the way that surveys were designed made a certain distortion unavoidable. Customs that the Koreans observed were not customary laws per se, and the very process of systemizing them into customary laws entailed codifying practices that previously lacked uniformity and communal agreement. Yet the surveys assumed that there already were uniform customs among Koreans, though this was far from the truth. ${ }^{16}$

That the surveys used as key sources textual material such as old legal codes from the Chosŏn dynasty and China contributed to the confusion. ${ }^{17}$ Using textual sources in customs surveys meant the risk of equating law-as-text with customas-practice. Especially in the premodern Korean context, where legal codes often functioned as ideals rather than norms, it was problematic to consider these as sources for customary laws. Codes on civil matters from premodern Chinese traditions reflected more the reality of the ideal than the reality of practice-should rather than is-and thus probably were not an optimal source for customary laws, indigenous as they may have been. Using written records as sources for customary law meant that customs that were being weakened could be revived. This might explain why some Koreans seemed exasperated by the customs that the Japanese colonial court decided to acknowledge, such as widow rights. Since the Japanese 
relied on old Chosŏn legal code books as a source, widow rights may well have been a dying practice, upheld on paper because of the moral purpose (e.g., widow chastity) it was serving. That also would explain why some of the customs listed on the Kanshū chōsa hōkokusho seem contradictory to one another: some customs were text-derived, and others may have been derived from practice.

In the process of compiling the Kanshū chōsa hōkokusho, local variations were erased. Korean customs were not nationally homogeneous. In institutionalizing a set of customary practices known as Korean customs, some customary practices inevitably had to be excluded and ignored. If certain customs were found to be in conflict with the overall framework of colonial law, they were not incorporated into the colonial legal system even if they fit a broad definition of national customs. For instance, even though concubinage was a widespread practice, customs related to concubines were not acknowledged as part of the customary law. ${ }^{18}$ Instead, concubines were banned from household registries in $1915 .{ }^{19}$ It thus was the practice of the colonial court not only to pick and choose among diverse customs but also to exclude those Korean customs that did not fit into the colonial legal scheme, replacing them with alternatives that usually were comparable to articles from the Japanese Civil Code. The end product was a nationalized version of customs that was new and alien to many Koreans.

Biases built into the survey process contributed to the problem of confusion. Local interviewees, for example, were drawn from the ranks of local notables, presumably with a penchant for customs that benefited them more than others (the younger generation, the poor, and women). In one customs survey, for example, all interviewees were men between forty and seventy years of age. They also seemed to have status: reports duly noted their occupations, most of which, such as "former head of township" or "member of Confucian student organization [chang'üi]" seemed honorary, but probably held a certain currency of local power. ${ }^{20}$

But beyond the design or method of the surveys, it was also the framework that proved problematic. The customs surveys operated on the assumption that the household system was already in practice, although the surveys were conducted before the household system was firmly established; this pushed the customssurvey process in the assimilatory direction. The survey questionnaires reveal that the household (ie) that formed the basis of status in the Japanese Civil Code was assumed to be in practice in Korea. While survey results detected that there was a complex and varying definition of the boundary of the family in Korea, questions such as "Is there a house that a son must enter?" simply assumed that households existed in Korea and differences existed only in procedural matters. Yet later reports drawn from local surveys conducted occasionally to supplement the Kanshü chōsa hōkokusho show that a continuing discrepancy existed in the legal framework of the household and the actual lived realities of family life. A 1919 report, which was conducted to determine the applicability of inkyo (retirement of the household head) in Korea, showed that Koreans preferred terms like 
chŏn'ga and kajang rather than inkyo or koshu, showing that the Korean sense of a $k a$ and its head was different from the Japanese sense of a household and its head (koshu). ${ }^{21}$ Given the built-in biases of the customs-survey process itself, accurately surveying customs in practice was a flawed project from the beginning. In other words, the boundary of the household that often played a definitive role in deciding family matters was a Japanese legal concept imposed not only on legal matters but also, from the beginning, on the process of surveying local customs. ${ }^{22}$

\section{WIDOWS CONTEST THE HOUSEHOLD}

Throughout the colonial period, there were 72 High Court cases that involved widows as litigants, most of which concerned widows' property rights. This was around 3 percent of all civil cases (2003 in total), but 30 percent of all cases concerning family matters and 40 percent of the 156 cases categorized under "Korean Civil Ordinances" (Chōsen Minjirei), the colonial civil laws that concerned Korean customs. Although this number may not seem high, these were just the cases that made it to the highest level of courts and thus a fraction of all the cases adjudicated in the local courts. The High Court cases are significant, moreover, because these decisions had wide-ranging impact as precedents. ${ }^{23}$ They were disseminated through official notices to the local courts and, after the Judicial Association was established, to all legal professionals through their monthly journal, Shihō Kyōkai Zasshi (Judicial Association journal). ${ }^{24}$

Widows' lawsuits uniquely illuminate the impact of the Japanese legal system on Korean families. Widows who were household heads literally embodied the boundary between the new colonial household and the lineage and thus often found themselves in a crossfire between the interests of the lineage and the interests of the colonial state. The new household regime, combined with clarified legal rights under the modern colonial legal system, meant that Korean women, especially widows, found themselves unexpected beneficiaries in the colonial legal system. Although such gains were not gains for all women, or for women's rights in particular, they demonstrate that the workings of colonial laws had a complex influence on women's status and legal rights under the colonial legal system: at the very least, the new colonial legal system breached the old system just enough so that some women were able to utilize it to their gain in unexpected ways. ${ }^{25}$

In January 1917, for example, two civil cases reached the High Court of Colonial Korea, one over the management rights of a piece of land and another over the ownership of harvest from that land. The land had been owned by a man who died in 1914, leaving behind a young wife and an infant son, who also died shortly after. The cases involved the widow, named Yi Se-sŏn, and the older brother of the deceased, Ko Sŭng-hwan. When Yi's husband passed away, Ko took charge of her husband's land and refused to give her any harvest from that land, prompting her to sue him. Yi argued that she had the customary right to retain her late 
husband's property and manage it until she found a suitable adoptee to inherit the household. Ko, on the other hand, argued that in the event a woman was widowed without an heir, it was "Korean custom to have a close (male) relative in the lineage [J: monchiu; K: munjung] manage the property," as women were dependents and had no rights over property, according to Korean custom. Yi won both cases in both the local and appellate courts, but Ko took the case to the High Court. ${ }^{26}$

Rather than demonstrating a sudden amnesia about what existing customary rights were for widows, this case, and many other cases over widow rights in the early years of the Japanese colonial period, more likely represented a continuity of conflicts and disagreements over widow rights. As we have already seen in chapter 1, widows' positions in marital families were increasingly threatened during the late Chosŏn dynasty, as the property regime came to favor land property, and daughters were excluded from inheriting land. By the end of the Chosŏn dynasty, widows, it seems, were victimized by contradictory standards: they were expected to remain single yet were subject to being sold in remarriage-sometimes against their will. The colonial civil courts merely provided a new venue in which these conflicts were enacted.

This case is notable because it shows how conflicts that were not new in themselves played out differently in the colonial legal system. First of all, the widow Yi pursued her own lawsuit. In a very similar case from 1906, before the onset of Japanese colonial rule, a widow's brother-in-law appealed on her behalf against a cousin-in-law who had taken the land title (chŏndap munkwŏn) previously owned by her late husband. ${ }^{27}$ The cousin-in-law had persuaded the widow to entrust the household's land title to him. Land titles, during the Chosŏn dynasty, were a critical proof of ownership. ${ }^{28}$ Since the widow's son was still young and the document needed safekeeping, the widow had agreed. Seven years later, when her cousin-in-law had not given her any of the harvest, the widow realized that she had been deceived and appealed to her brother-in-law for help. It is significant that the widow from 1906 did not directly put forth the lawsuit herself, unlike the widow $\mathrm{Yi}$, who did. ${ }^{29}$

A more striking difference in the colonial legal system, perhaps, was how matters of widow rights became the subject of official legal attention, and civil lawsuits such as these became opportunities for the colonial legal system to clarify customary rights. The High Court sided with the widow Yi in the 1917 case. It refuted the brother-in-law's claim that Koreans categorically denied property rights to women. As a widow and now the household head of her family, Yi, the judges stated, had the right to inherit her late husband's property and manage it until she adopted an heir. Such decisions would later be used as precedents in rulings when similar cases emerged.

Widow rights themselves were not an invention of the colonial legal system. As explained in chapter 1, widows had special customary rights in Korea before the colonial period. An eldest daughter-in-law (chongbu) of the family had a special ritual standing, and, in cases where the family head died without an heir, the daughterin-law was eligible to continue the ancestral rites and adopt an heir to continue the 
family line. To suppress the remarriage of widows, the Chosonn court allowed widows to keep their husband's rank land as "chastity land" (susinjŏn). Yet these rights were continuously challenged at court, for they clashed with the principle of patrilineality, as the trend toward exclusive agnatic inheritance grew stronger after the seventeenth century. An inheritance regime that flowed through bilateral lines gave way to an inheritance regime that gave rights exclusively to agnatic kin. A long tradition of partible inheritance also gave way to primogeniture, further marginalizing daughters' inheritance rights in the family. Widow rights seem to have been uneven and weakening, especially among commoners, by the late nineteenth century.

There are several likely reasons why widow rights were acknowledged under the colonial legal system as legitimate Korean customs. First of all, widow rights served a practical purpose in the legal system by filling an important gap necessitated by the colonial household system. In the household system, where the household head had an important legal capacity, succession needed to happen immediately after the household head's death. Therefore, there always needed to be a designated heir in any given household. In the absence of daughters' inheritance rights, having a widow as the backup heir was a necessary provision for households that lacked sons as heirs. Yet the strong tradition of agnatic inheritance in the Korean family system, centuries old at this point, dictated that family property had to pass into the hands of agnatic kin and denied widows permanent inheritance rights. The administrative need for a backup heir, yet the customary resistance to giving widows full inheritance rights, produced colonial widow rights that were neither full inheritance rights nor an outright lack of rights.

Parts of the Kanshī chōsa hōkokusho do give credence to the argument of the brother-in-law who denied independent property rights for women. Item 5, "Are There Restrictions in the Wife's Legal Capacity?", notes, "In Korea, the wife must be absolutely obedient to the husband ... and in all legal transactions (contracts, lawsuits, and other important legal actions) must receive permission from the husband." Item 132, "What Kind of Rights Does the Husband Have over the Wife?", notes again that the husband's power over the wife is mightily large and that the "wife must always receive permission from the husband in all legal matters." ${ }^{30}$

Yet widows and their rights and status were another matter. Descriptions from the Kanshu chōsa hōkokusho show the ambivalent and vague nature of widow rights. Item 164, "What Happens When There Is No Legally Assumed or Designated Heir to the Household Head?" clearly states that the widow of the household head had the right to choose the heir when the household head died without one: "When the household head dies without an heir to conduct ancestral rites, an heir needs to be chosen, which amounts to nothing less than the action of adopting a son after the death of the adoptive father. The person to decide the adoption is the wife [that is, the widow]. If there is no wife, then this responsibility falls on the mother [of the deceased household head]. If neither of these persons is alive, then the lineage association is to decide the adoption." 
Yet custom was more equivocal about the inheritance of property. Item, 168, "Who Can Become the Property Heir?," states,

When the household head [koshu] (except for a female household head) dies, the heir to the property is the same as the heir to the ancestral rites, others who can perform the ancestral rites, or the deceased's brother. A daughter cannot become an heir to property. The heir has to be someone within the house; someone [living or registered] in another house [take ni oru mono] cannot become a property heir. ... When there is no son, [one can] either have the wife accept [ukuru] the portion of inheritance or choose an adoptee and have him accept the adoptive father's portion of inheritance, but the custom is inconsistent on this point.... If the deceased family member does not have a son and if the deceased is the eldest son, the inheritance is passed on [shōkei] to his father. If he is a younger son, the property is passed on to his wife. If the [deceased] family member is not married or is a daughter, the inheritance is passed on to the father. ${ }^{31}$

In other words, according to the Kanshū chōsa hōkokusho, when there was no suitable heir, the widow could "receive" property. But the description itself was conflicted: the widow could receive property, but, as a woman, she could not become heir to property. Because the purpose of these descriptions was to clearly designate heirs, it established the widow as the last resort for passing on the family property when there was no heir but made sure that she had only temporary rights over the property until an heir was chosen. The Kanshū chōsa hōkokusho also states elsewhere, "People do not acknowledge retirement of a household head in Korea, but when a widow household head has adopted an heir for the deceased male household head, the adoptee, of course, becomes the household head, and the widow who had been the household head [retires and she] and her family members become his family members." 32

Since the Japanese also wanted to maintain the household as the only legal unit of family, widows were critical to keeping the property within the household and preventing the property from being subsumed into the main house, thereby obliterating the particular household. The problem was that there was no legally defined tenure of a widow in the household-head position. Widow rights were acknowledged, but the contours of their rights were not clearly delineated. This ambiguity not only subjected widows to vulnerability but was bound to cause problems and, indeed, became a source of contention as well.

\section{THE COLONIAL REGIME RECONFIGURES THE HOUSEHOLD}

Widow cases show that more than Korean customs, it was the new household framework that determined the outcome of lawsuits. The colonial household system implemented through household registration thus deeply affected family life in colonial Korea. The civil-registration system was introduced in 1909, and the 
Civil-Registration Law (Minsekihō) required all Koreans to register by household units under the name of the household head (J: koshu; K: hoju). Also noted in the registers were the address of the family and the names and dates of status changes of all family members, such as births, deaths, marriages, divorces, adoptions, and recognition of (the paternity of) children born out of wed-lock. ${ }^{33}$

To be sure, family registration itself was not new in Korean history; it was the legal function of it that was new to Koreans. Records of registering king's subjects in household units date as far back as the Three Kingdoms period. The Koryŏ and Chosonn courts also required subjects to register with the state. The purpose of the Chosŏn dynasty family registers was to clarify personal status for the yangban elite and to levy corvée and head taxes on commoners. ${ }^{34}$ The unit of the family registered was the unit of coresidency, including family members but also any relatives, slaves, or hired hands that shared the residence. The term, head of the household (hoju), also was in use since the Chosŏn dynasty, but the role of the household head was entirely different from that recognized by the colonial registry: in the Chosonn dynasty the household head was simply a representative of the family responsible for paying the household tax to the state authorities. ${ }^{35}$ Rather than a position of authority, the household head performed an administrative function. Therefore, taking on the duties of the household head in the place of an ailing father or an aging mother could even be considered an act of filial piety ${ }^{36}$ Surveys from as late as the 1920s show that Koreans had a concept of chŏnga (passing on the family), meaning passing on the position of hoju, or kajang, to a younger family member when the older hoju had grown too old to properly perform the administrative role. ${ }^{37}$ The Kwangmu Registry, a reformed household registry put in place shortly before the onset of Japanese rule between 1896 and 1907, as part of Kojong's efforts at strengthening the court administration, did not change much in these regards. The objective of reflecting the lived reality of the family was strengthened: the focus was on accurate depictions of who lived within the family, regardless of their relations..$^{38}$ In short, although previous forms of household registries existed in Korea, their function was an administrative identification of the household composition, with the household head serving merely to represent the family.

The Japanese-installed household registry differed from previous Korean versions in some significant respects. First, it imposed a particular family structure rather than accurately reflecting existing coresidence patterns, as the Kwangmu Registry, for example, had aimed to do. ${ }^{39}$ In the Japanese-installed system, the household head and family members were registered, while other unrelated coresidents-such as servants, who had been registered in the Kwangmu Registry-were excluded. Patriarchal principles and primogeniture also were imposed for inheritance of the position of the household head. Unlike in the previous Kwangmu Registry, the ability of an eldest son to divide his household from the parents' household was restricted; as a result, within the first few years of the 


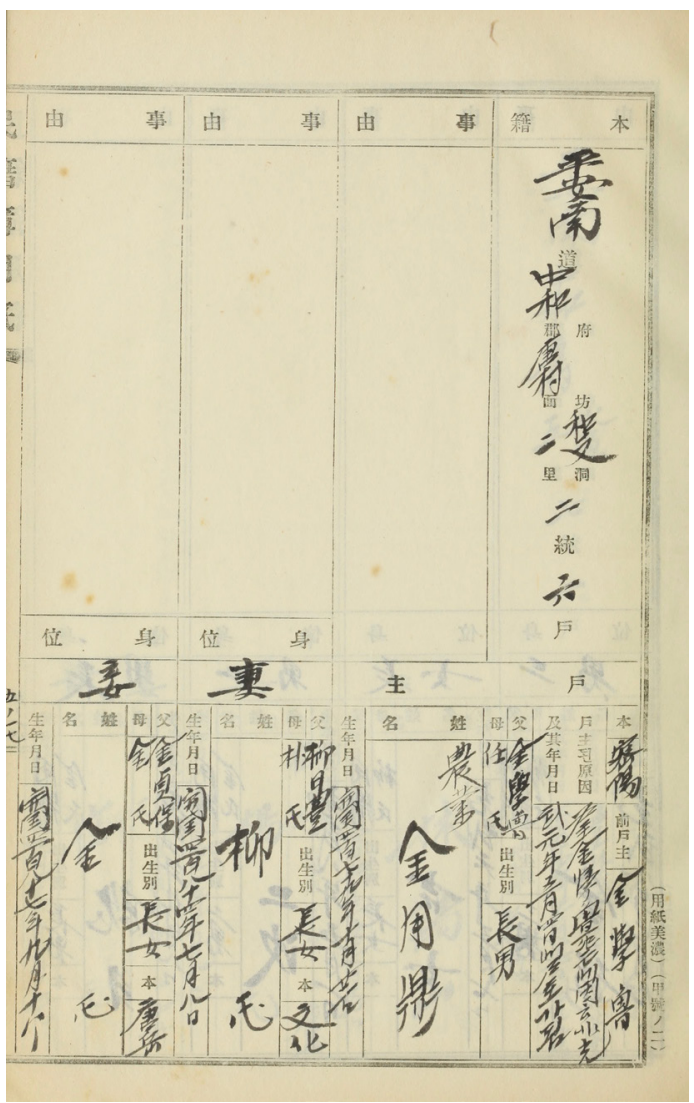

FIGURE 1. A page of a household register with a wife and a concubine. From Ariga, "Kosekini kansuru jikō."

Household-Registration Law's promulgation, families were restructured to follow the newly normative structure of the patrilineal stem family..$^{40}$ The household registry recorded the personal status of all residents in a household unit under the administrative authority of the household head, whose position was inherited according to principles of primogeniture and patrilineal succession. The household head held both legal and economic power, with the authority to approve all status changes of family members, such as marriages, divorces, and the registration of births, as well as the right of an individual to claim a larger portion of family property in inheritance. Validation of family status changes that used to be in the realm of the family and the community were now moved to the realm of government administration. Through the Japanese-installed household registry, the relationship between the state and society was reconfigured, and the Japanese colonial apparatus inserted itself into the private space of the family. ${ }^{41}$ 


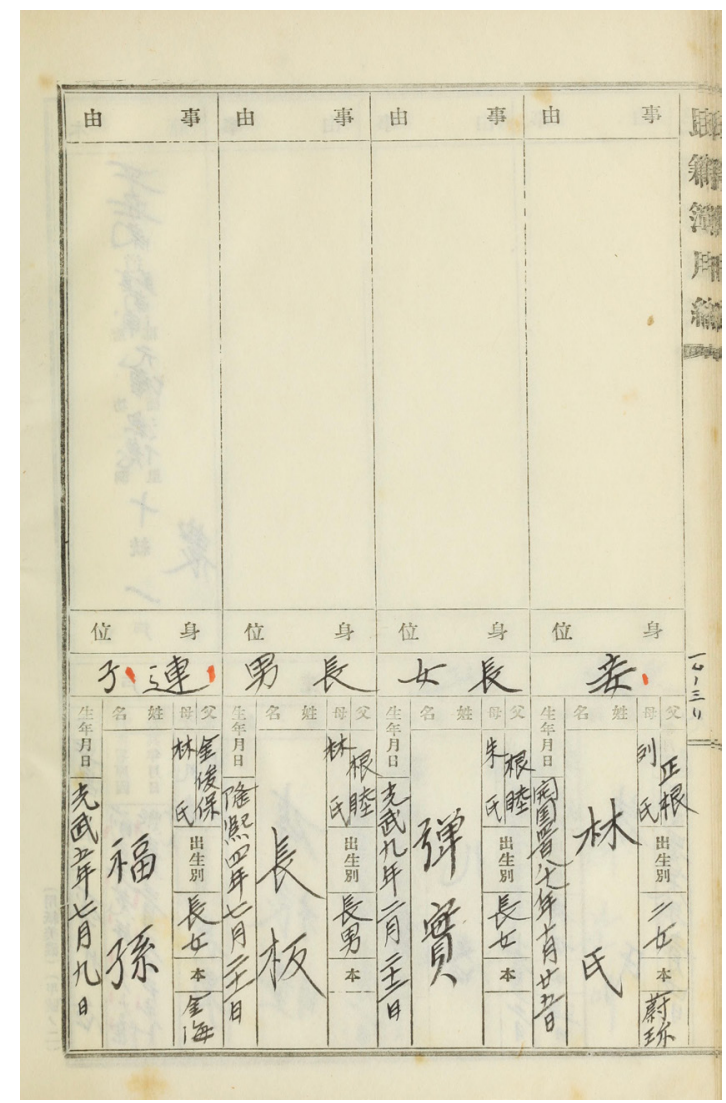

FIGURE 2. A page of a household register with a concubine and a daughter she brought in. From Ariga, "Kosekini kansuru jikō."

In addition, the registry officially transformed the definition and boundary of the family. The household that was registered was not a simple reflection of the actual coresident family. It privileged the definition of family that centered around consanguinity, that is, relations by blood organized around the principle of patriarchal hierarchy. The collection of household registers from 1913, gathered presumably in preparation for the 1918 Common Law (Kyōtsūhō) and the 1922 Household-Registration Law (Kosekihō), shows that there was a significant gap between the proper household that the colonial state was trying to enforce and the actual lived realities of Korean families. ${ }^{42}$ Among the registers collected for their peculiarities were those of households with both a wife and a concubine, households with tsureko (children from a wife's previous marriage), households headed by a widow living with a daughter and a son-in-law, and households of 


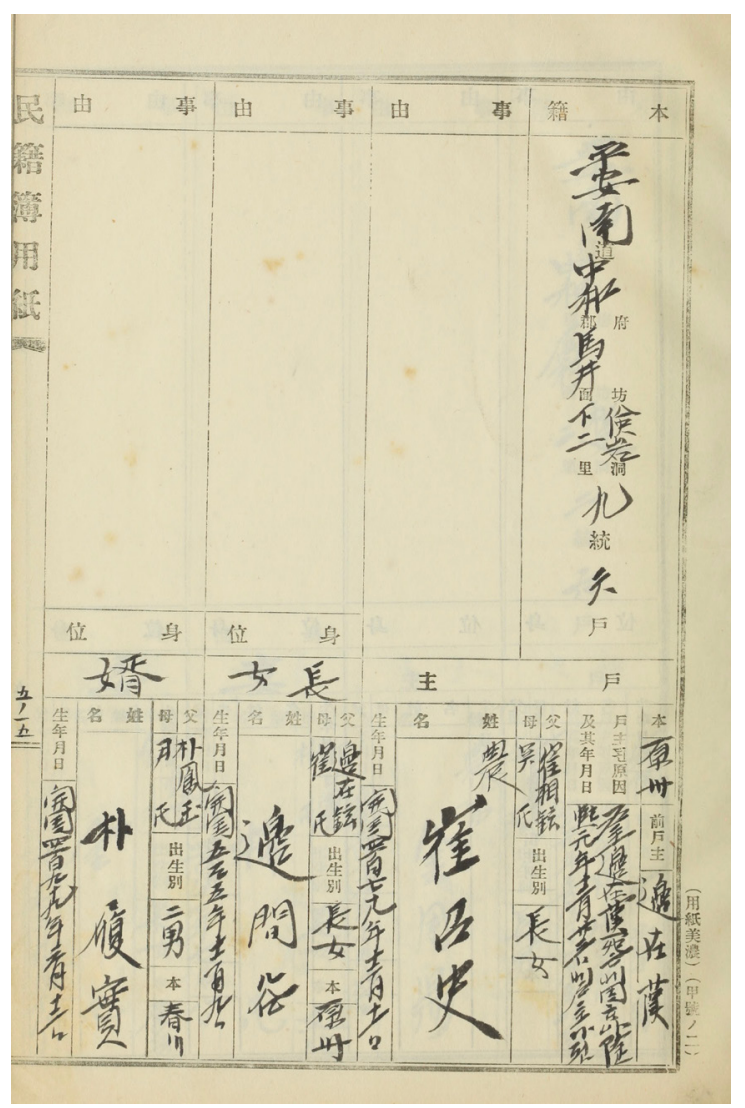

FIGURE 3. A page of a household register with a widowed household head and her daughter and son-in-law. From Ariga, "Kosekini kansuru jikō."

monks, a group of unrelated people who yet shared one residence and economy.43 These were all groups of people coresiding in one household, reported by those people themselves as a household, that nonetheless were considered by the colonial state unfit to be considered as proper households. Clearly, the household in the registry was meant to be more than just a reflection of the lived reality: it was an abstract legal concept imposed on the lived reality. In fact, this concept of a household unit was the first instance of the extension of metropolitan family law into Korea, even before Korea was formally colonized. ${ }^{44}$

It was the new boundary of the family that most critically determined the outcome of many of the cases that involved widow rights. In the previously mentioned case from 1917, the brother-in-law, Ko, lost the case because his claim to be a family member of the widow was denied by the judges. According to the appellate court 


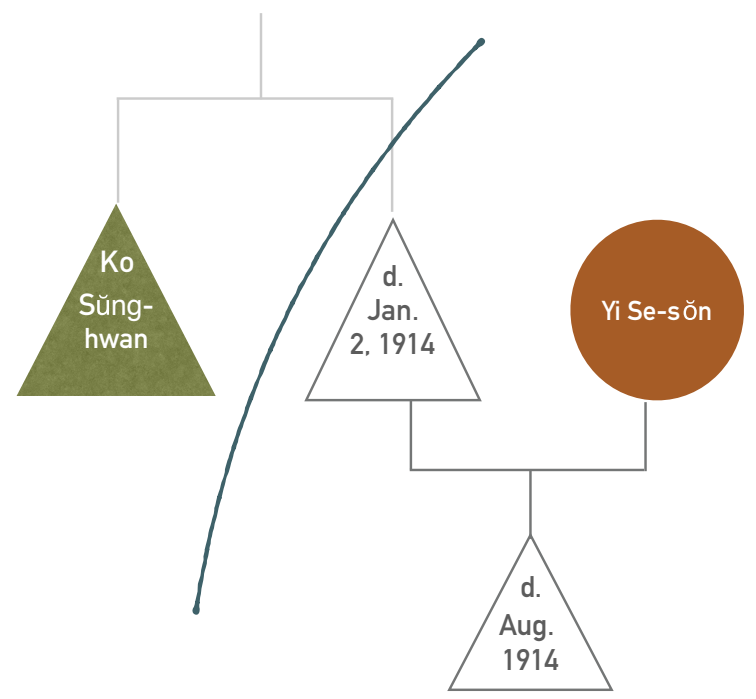

FIGURE 4. A diagram of the Yi Se-sŏn case.

judge, Yi Se-sŏn, the widow, was the only family member left to inherit the property until a suitable heir was found. To this, Ko adamantly protested, "According to Korean custom, brothers are one body and are of one family regardless of whether they live together. It is also without question that the brother's wife is one family." To this, the High Court judge noted, "Once a household is divided, the household head of the divided house and his family members are not family members of the main house. ... Therefore, it was right for the original decision to not acknowledge that defendant [Yi Se-sŏn] is plaintiff's [Ko's] family." 45

The judge was subtly but surely changing the definition of family from kinship to the legal unit of registration. The new household implemented through the colonial registration system thus clashed with the traditional family system in Korea, which had placed a strong value on consanguinal ties. The principle of the Ordinances on Civil Matters that decreed family issues in Korea were to be dealt with according to Korean customs did not stop the colonial state from imposing this new boundary of the family in Korea. This and similar decisions articulated a new boundary of the family: one defined by the Civil-Registration Law, whereby the boundary of the family was circumscribed to correspond to the boundary of the household. All informal family ties were deemed legally irrelevant. In the process widow rights, perhaps unbeknownst to the litigants themselves, were strengthened as the claims of in-law relatives were curtailed along the household boundary.

The case of Yi Se-sŏn, therefore, shows how widows benefited inadvertently as the placeholders of the boundary between the household and the lineage. In this, 
as in all the cases where widows' property rights were upheld, what was really being confirmed was the legal boundary of the household. Upholding a widow's right to inherit the household property directly enforced the boundary of the household. Traditional rights of the widow in this way found new support from the colonial regime. The protection of a widow's right to her deceased husband's property may have been one of the most striking ways in which the Koreans learned about the everyday consequences of the household system. In the previously mentioned case, the appellate court stated, "Even though the plaintiff argues that there were customary rights for a household head to manage the property for a widow when her husband dies without an heir, the husband in question died after he had divided his household from the plaintiff's household, and therefore the plaintiff has no such rights to claim. ${ }^{46}$

With the establishment of the new boundary, the legal rights of relatives outside of the household boundary also were denied. Customarily legitimate but informal family titles were suppressed in favor of the new legal terms dictated by the household-registration system. To Ko's claim of rights as a "lineage relative," the colonial court responded with another term, "household head," the legally recognized position in the household with prerogatives over family property. In other words, the colonial court was denying legal recognition to property claims based on lineage ties rather than household membership. The widow's right to inherit her dead husband's property and the brother's failure to extend his power over that property protected the boundary of the household. The competing definitions of family boundary offered by Ko and the colonial court not only reveal a wide disjuncture between the colonial law and the local customs of the colonized but also show that these differences were constantly (and sometimes covertly) negotiated to facilitate the colonial system. Even though family matters were to be ruled by Korean customs, certain Korean customs were discarded, ignored, or drastically modified to fit the Japanese legal framework and Japanese objectives.

To stress the new boundary around the household, judges on the High Court sought help from a different customary concept: "separate register, separate property" (J: besseki yizai; K: pyŏlchŏk yijae). Originally, this was merely a term that designated a separated house, very similar to the Japanese legal concept of bunke (divided house) or bunseki (separated registry). In legal documents from the Koryŏ and Chosŏn dynasties the concept pyŏlchŏk yijae was used to discourage separating a register and dividing a house when the parents were alive. ${ }^{47}$ Yet the term in the High Court was used to mean something different and prescriptive: if they had a separate register, their property was also separate. Cases that drew on this principle followed exactly the same logic as the Yi Se-sŏn case and show that the colonial court was consistent in its effort to enforce this new legal boundary of the family. As early as 1911, the judges stated that, according to the Korean custom of "separate register, separate property", a relative outside of the household could not inherit the household property. This case also involved a male relative of 
the husband's family protesting the widow's inheritance of her deceased husband's property. ${ }^{48}$

In another case that also cited this principle - the 1913 case of Chŏng In-su versus Yi Tong-sik - the court ruled that Chŏng could not inherit from his grandfather's concubine, Madam Chu (Chu-jo'i), because she was registered in a separate household register from his. Her property instead was passed on to Yi, her nephew, whom she had designated as her heir. ${ }^{49}$ This decision also curtailed an existing family tie, that between a mother and a child, prescriptively imposed between a father's spouses and his offspring. Chŏng In-su based his claim to inheritance on his perceived, or culturally prescribed obligation, to support Mme. Chu in her old age, reflecting traditional family sentiments. To this claim the High Court judge replied that he was not a family member of the widowed concubine. In fact, under colonial law Chŏng no longer had the obligation to care for his grandfather's concubine. Under the new law, which encouraged monogamy, adding concubines to the household registers was banned, and the familial relationship of the concubine with her husband and his proper wife's children was officially severed. As such, this new legal condition gave concubines like Mme. Chu the opportunity to free themselves from the husband's family, allowing them to become heads of their own household. They were then free to bequeath their property to whomever they designated, someone they could trust to honor their souls with annual ancestral rites. For Mme. Chu, that was not Chŏng In-su, her "grandson."

\section{HOUSEHOLD AND PROPERTY OWNERSHIP}

Redrawing the family boundaries had a larger implication than just reorganizing the family system. It also meant drastically restructuring property relations within Korean society, shifting land from communal ownership to ownership by individual heads of households. When the colonial land surveys compelled landowners to register their land with the colonial administration, it enforced the concept of individual ownership that denied customary rights such as surface or tenancy rights, causing great confusion and distress to tenants who had enjoyed long hereditary rights of tenancy and cultivation over the land..$^{50}$ Because this new colonial definition of property ownership meant that there was only one owner per parcel, many families were thrown into chaos by the need to delineate the prerogatives of the lineage heir. Once the heir of the core family was declared to be the land's sole owner, traditional restraints on his ownership (especially in terms of selling or mortgaging the land) also became ineffective. As is shown in the following cases, the family patriarch became no longer able to claim rights to property owned by members of his family who lived outside of his household, even if the traditional norms had prescribed otherwise.

One of the areas where the new colonial property ownership wreaked particularly serious havoc was that of ritual estates (wit'o), agricultural lands set aside by 
the lineage to fund ancestral rites, the managerial rights to which were granted to the heir of the main family. While the colonial government nominally continued to acknowledge the communal ownership of such land by the lineage, this principle sat awkwardly within the overall structure of individual ownership that precluded any restrictions by customary rights of communal ownership.

This conflict was visible in the following cases from the 1910 s concerning burial sites as well. Burial-site cases were categorized separately among Korean customrelated cases in the High Court decisions. The perception was that burial sites had a special customary status that marked them as different from other landed properties. Indeed, the litigants involved in burial-site cases did cite a special set of customs that constrained the general concept of property ownership under the colonial legal system. There were customary distances between grave sites that needed to be observed, which varied according to the buried person's status, both social and familial. Problems arose when the owner of a burial site did not own all the extra space that custom designated as the necessary space to be left empty. When another person who owned within this extra space buried his own relative in it, a conflict would break out with the owner of the first burial site, who would protest that the second person was violating his customary rights. At heart, this was a conflict between customary rights and personal ownership. Invariably, the colonial court ruled in favor of the latter. If the owner of the first burial site did not own all the customary land around the burial site, he could not protest another person's use of this land..$^{11}$

In 1911 the High Court heard a particularly messy case concerning a grave site. $^{52}$ This case between two family members shows how traditional familial propriety or customary rights had lost ground to the claims of individual ownership instituted by the new colonial regime. More pointedly, it shows how the new focus on exclusive ownership functioned to curtail the customary claims of lineage that had spanned family boundaries. Within the framework of exclusive ownership of property, the customary rights of the core lineage family over other families based on ritualistic grounds were no longer sanctioned. This case involved the plaintiff-a second nephew of the accused-burying his father on land that the accused claimed as his. The accused went to the police, claiming that there was an "unidentified body" in his land. Failing to find the person who had buried the body, the police exhumed it. The plaintiff was suing to have the body reburied at the site. As it turned out, the burial site was part of a larger patch of land that the plaintiff's great-grandfather had given to his younger brother, the accused's grandfather. While agreeing that the land was given to the ancestor of the accused, the plaintiff argued that the burial site itself was a "shamanistic ground [ŭmsaji]" and therefore excluded from the gift. Arguing that the injunction that had forbidden anyone from owning this shamanistic ground was now lifted, he stated that it should be returned to its rightful heir-himself-as he was the great-grandson of the original owner. The accused, meanwhile, denied any 
such customary restrictions on the land. One can assume that before the institutionalization of registered ownership, customary propriety binding these two relatives would have prevented the accused from exhuming the body of a second cousin buried on his land. After all, the deceased second cousin of the core family would have had a ritualistically higher position. Stating that there were no such customary restrictions based on the plot's being a "shamanistic ground," the colonial court upheld the accused's right of ownership. Since the accused had the right to decide whom to bury in his land and since he had done all he could to find the person who had buried the unidentified body, his decision to exhume was deemed entirely justified.

Owing to similar complications, further cases concerning communal ownership were presented in front of the courts in 1915 and 1916, including two cases of lineage members who had sold their communal land without the consent of other lineage members. ${ }^{53}$ In both cases the lineage members had registered the communal land under their names as individual property and conducted the sales with proper seals and documents. Although the High Court acknowledged the communal nature of both pieces of land, there was little that the court could do to prevent these individuals from claiming the communal lands as their own beyond rebuking the individuals for foregoing the customary process of consulting the other members of the lineage before the sale.

The new land-registry system, launched after the land surveys that the Japanese colonial state conducted between 1910 and 1918, also strengthened householdhead rights over property, curtailing any kinship ties or cultural convention that attempted to override such rights. In the sense that both systems strengthened household-head rights, the property cases over ancestral burial grounds were similar to widow cases like that of Yi Se-sŏn. Putting widow cases in the context of such other cases thus challenges us to evaluate widows' victories in inheritance cases within a larger picture. The victories of widows, it seems, did not particularly mean that the colonial courts were extending women's property rights per se. Rather, the colonial court was showing a consistent and marked preference for upholding the new household boundary and protecting the colonial household against the extended reaches of the lineage. As with the aforementioned landownership cases, the women triumphed in court only because the denial of their claims would have meant a threat to the boundary of the household unit.

The new household unit, therefore, had dual functions: limiting the authority of the patriarch over the extended kinship and defining a new boundary around the household that was enforced by and legible to the colonial state. In other words, although it preserved a certain collectivity of the family unit, the Japanese colonial state did so by significantly disrupting the existing collective unit of the lineage. Although both family systems strongly espoused patriarchy, there were crucial differences in their definitions, especially in terms of family boundaries, giving rise to strong conflicts between the two systems. Therefore, the critical impact of the 
Japanese Civil Code in colonial Korea was not that it strengthened or weakened the patriarchal ideology but that it enabled the colonial state to define the boundary of the family on its own terms. In this way Japanese colonial family law forged a new relationship between Korean families and the colonial state as the state tried to get rid of the competing object of loyalty, the lineage. With the new family law, lineage power was weakened, making the resultant colonial household much more directly accountable to the state.

Interestingly, this imposition of the household boundary on informal reaches of kinship also existed in Japan, even before the Meiji Civil Code was promulgated. One 1878 case from Japan suggests that the household had a similar effect of curtailing larger kinship ties. This case, which occasioned a Japanese Supreme Court (Daishin'in) decision on July 27, 1878, involved a civil suit between Arabe Ryūji and his father, Arabe Heizaemon, over the issue of household inheritance. ${ }^{54}$ In 1858 Ryūji separated his household registry (koseki wo waketa) as an older son; in 1878 Heizaemon retired as the household head and passed the household on to his younger son, Heijū. A year later, however, Heijū passed away without a son, leaving the family scrambling to find an heir. When Heizaemon passed on the inheritance of the household to Kama, his daughter and Heijū's sister, Ryūji objected, saying that his son, Koji, was the rightful heir. Ryūji argued that only sons could be household heads; daughters could be made heirs only when there were no suitable sons. The Supreme Court, however, backed Heizaemon, ruling that Ryūji, as a member of another household, had no right to meddle in the Heijū household's business of deciding an heir-neither could Ryūji send Koji, his proper son (chakushi) and an eligible heir to his own household, to another household.

The case touched on many issues of central concern within the contemporary debate in Japan over family law (e.g., issues of daughter inheritances, household boundaries, and divisions of a household). While the principle of inheritance was formulated to support the prerogatives of the household head, its enforcement in practice did not necessarily result in the strengthening of the collectivity principle. Instead, by strengthening the enforcement of the household boundary (i.e., when the boundary of such a family violated the boundary of the household), it could have the opposite effect. This was partly related to the state's desire to prevent the hasty division of households by families to avoid military conscription. But the most striking aspect of this particular case was the state's desire to implement its own version of the family boundary, as recorded in the household registers, rather than acknowledge the nebulous ties of kinship claimed by the litigants. In this way, even as the Meiji state was struggling to reconcile various visions of the Civil Code, it ensured that old informal and private ties of kinship would be regulated by the administrative boundary of the family that matched the official household register legible to the state. Thus, the boundary of the family came long before the principle of household collectivity or the authority of the household head, which became increasingly important after the promulgation of the Meiji Civil Code in 1898. 
The implementation of the household system strengthened the household boundary against claims of kinship authority from outside of the household. In many lawsuits widows could take advantage of the strengthened boundary of the household and inherit family property (ownership or management) over in-laws. Such decisions were not inspired by the need to expand widows' rights at large, let alone women's rights. The following section analyzes civil lawsuits in which widows were involved to show that many of the widows' victories were a doubleedged sword: as these decisions strengthened household-head rights they weakened widow rights because widow rights, as well as the rights of all the household members, were subsumed by the strengthened rights of the household head.

With the strengthening of the individual rights of the household head, widows became more vulnerable to the actions of the male heir. It became almost impossible, for one thing, to cancel an adoption, because that would mean disinheriting a household head. Also, personal influence over the adopted son, which used to be culturally acceptable, became defunct under the colonial legal system. A case in 1912 illustrated the precarious status of a widow under the colonial household system. On May 28, 1912, a lawsuit erupted over a property sale that a widow had made. 55 The plaintiff, Pak Chi-yang, was the adopted heir of the household and claimed that the property that had been sold was his. The accused, Choe Chong-u, claimed that he had obtained the property from the widow of the household, Madam Chu. Choe argued that although Pak had been adopted as the heir, the widow later disinherited (rien) him, so he had no rights to the inheritance. In the first trial, Choe won. The local court acknowledged the fact that Madam Chu had disinherited Pak and that he therefore had no rights to said property. In his appeal Pak argued that, according to Korean custom, once he had become the household head, the elders of the household could not disinherit him. The inheritance thus was legitimate according to Korean custom, and the decision of the local court was mistaken. Moreover, he added, "Madam Chu was merely a concubine [hwachöpliterally, flower concubine, i.e., a young concubine of an older man], and did not have the authority of a household elder to disinherit the adopted heir." The High Court accepted Pak's argument. It ignored the accusation that Madam Chu was a concubine-she was probably a wife of remarriage-but conceded that even if she were a proper household elder, she had no rights to disinherit Pak once he had succeeded to the household headship.

This case demonstrated how the High Court specifically tried to strengthen household-head rights through stabilizing the household-head position. The decision contradicted the court's own decision on a different case in the same year. In 1912 the High Court permitted a family to disinherit an adoptee who had succeeded to the household headship on the grounds that the adoptee was chosen from the wrong generation of agnatic kin, violating Korean customary laws of adoption..$^{56}$ Although the Korean custom of somok stipulated that the adoptee had to be from one generation below the inheritor, the family chose an adoptee 


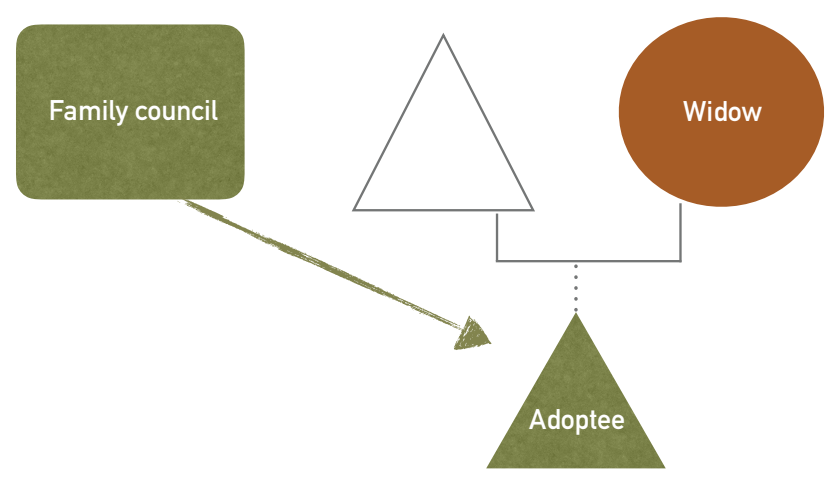

FIGURE 5. A diagram of the 1933 case, where the widow refused to adopt an heir.

from the same generation. The High Court stated that the ban on disinheriting an adopted heir once he had succeeded as household head was not an established custom at the time. Also, to acknowledge an exclusive right for the household head over which even the household elder had no influence was definitely a transformation of Korean custom. The court acknowledged not only that the household head shared his ownership with no one but also that he had full legal authority over the household property without having to answer to any other authority in the family. This, one could say, was a covert assimilation of Korean inheritance custom to Japanese custom. And, as a result, the property rights of the household head were strengthened. More important, widows and other elders of the household were further constrained from exercising power over the household property. Unlike her Chosŏn dynasty counterparts, who exercised moral authority over the household head, whether he was her descendent or adopted, the widow of the colonial period had no such recourse; she was cut off from the household property once she selected the heir and passed the household-head position on to him. In other words, even though the widow's right to designate an heir was a powerful one, once the heir was chosen, she had no power over the heir or the household property.

Not all widows were resigned to this disadvantageous position. In October 31, 1933, the Chōsen High Court delivered a decision on a lawsuit that a widow had brought against the family council that arranged an adoption for her. ${ }^{57}$ The widow argued that she did not acknowledge the adoption and therefore it was invalid. The family council's side argued that it had to act only because the widow was negligent about arranging an adoption. The widow claimed that her deceased husband left her a testament telling her specifically not to adopt; she was merely respecting her husband's death wish. The head of the family council argued that, according to Korean custom, it was the widow's obligation to adopt a male heir to carry on the ancestral rites, and the husband's testament prohibiting the adoption, 
therefore, was invalid. The widow then pointed out that the adopted heir designated by the family council was a frivolous spender who was bound to ruin her family business. If the family business were ruined and the family turned out into the streets, how would the ancestral rites be continued? This was precisely why her husband left the will, she emphasized, warning her not to adopt an heir. Did a widow in Korea have the choice not to adopt an heir? Benign as it sounded, the widow's query revealed the critical ambiguity in customary widow rights in colonial Korea: the widow household headship was supposed to be temporary, but there was no explicit rule regarding its duration.

Claiming that she was obeying her husband's testament, what the widow was really doing was utilizing a loophole in the legal system to claim permanent ownership of her husband's estate. In the end, the widow won the case and was able to dissolve the unwanted adoption, though she was not given permanent rights over the estate. The court merely concluded that the widow's refusal to accept the heir in accord with her husband's testament could not be interpreted as a "willful refusal to adopt." The High Court dodged the demand to pass a clear decision on the matter, but the case revealed the heart of the problem with customary widow rights. The lineage's interest (represented by the family council) and the widow's interest were put into deadlock by the temporary nature and the obscure boundary of widow rights. The legal limbo that the colonial court chose is understandable, because the colonial court itself was put in a quandary. Widow rights were something to be phased out (as its conceptual basis was in the lineage system), but without daughter's rights to the household headship, abolishing widow rights could only strengthen traditional lineage power.

\section{CONCLUSION}

I have examined how the new unit of the family installed through the household registers functioned to strengthen customary widow rights. Contrary to what conventional understanding would suggest, and also contrary to the experience of some widows subject to utter mistreatment because of an absolute lack of power, many widows were successful in having their customary rights acknowledged in the colonial court system. These widows actively fought and won against their inlaw relatives who claimed in the colonial courts that Korean custom denied any inheritance rights to women. The colonial court system and the customary laws created through this system, in fact, benefited the widows subject to diminishing rights under strengthening patrilineal lineages on the eve of Japanese colonial rule.

Yet I argue also that strengthened widow rights were accompanied by strengthened household-head rights. Even though the 1912 Ordinances on Civil Matters seemed to acknowledge Korean custom in family matters, this acknowledgment happened only in the context of the household system that had been implemented in 1909. The household system already significantly redefined the family boundary 
and affected how Korean family custom was interpreted and applied in the colonial courts. As a result, widows who could become and remain household heads benefited, but those widows who passed the household-head position to adoptees too soon sometimes felt mistreated. The strengthened household-head rights meant that the traditional authority of mothers who could challenge householdhead rights was denied. Once the heir assumed the household-head position, there was no one in the house who could disinherit him. The problem with widow rights was mostly from their poorly defined nature. A widow's right to ascend to household headship was only temporary, good only until she designated an heir to whom to pass on the position and the household property. Much contention thus arose because when this adoption needed to occur was not clearly defined. Indeed, the frequency of cases concerning widow rights seems to attest to the unstable nature of widow rights in the context of a modern property regime where clear property relations were key. Eventually, the colonial state tried to solve this problem by replacing widow inheritance with daughter inheritance, the issue to which we turn in the following chapter. 